\title{
Charophytes Locality in the Ga'aton River, Lower Galilee, Israel
}

\author{
Dr. Sophia Barinova (Corresponding author) \\ Institute of Evolution, University of Haifa, Israel
}

Tel: 972-4-8249697 E-mail: barinova@research.haifa.ac.il

Prof. Roman Romanov

Central Siberian Botanical Garden of the Russian Academy of Sciences, Russia

E-mail: romanov_r_e@ngs.ru)

Received: December 19, 2015 Accepted: January 17, 2016

doi:10.5296/jbls.v7i1.7815 URL: http://dx.doi.org/10.5296/jbls.v7i1.7815

\begin{abstract}
First study of new locality the Ga'aton River, the Lower Galilee, with charophyte algae, in semi-arid to temperate region of Israel has been implemented for revealing of algal diversity and ecological assessment of the water object environment by bio-indication methods. Altogether twenty species from five taxonomic Divisions of algae and cyanobacteria including one of them macro-algae Chara grovesii B.P. Pal were revealed in the Ga'aton River. This is the first species record for Israel and Mediterranean region. Chara was found in growth in the middle part of studied stream. Bio-indication and chemical variables characterize the charophyte sites environment as fresh, low alkaline, and low to middle organic pollution with mainly eutrophic state. Saprobity index $\mathrm{S}$ is fluctuated in small range (1.83-1.93) and reflect low to middle organic pollution, Class III of Water Quality. The river environment can be characterize as natural to anthropogenically impacted from the river basin with Aquatic Ecosystem State Index WESI about 0.50-0.57 and tendency of self-purification down the river. The Ga'aton River can be recommended for regularly monitoring of chemical and biological variables in purpose the watershed management and protection.
\end{abstract}

Keywords: Charophytes, Ecology, Bio-Indication, Lower Galilee, Israel 


\section{Introduction}

The charophyte algae in Israel has been studied sporadically and represented by four species only (Rayss, 1951) from habitats that are missing now. Diversity of algae we study intensively from 2000 as regular work in the rivers and other water bodies (Barinova, 2011a). As a result we studied known localities as well as find new localities not only for algal diversity update but especially for charophyte macro-algae revealing. In present time we revealed 14 charophyte species (16 with ifraspecific variety) that known for Israel (Romanov and Barinova 2012; Romanov et al., 2015) from references and our studies. Last year research in Israel let us too includes few new localities, algal diversity of which has been never studied before (Barinova and Romanov, 2014a,b; 2015a,b,c).

The charophytes are very distributed in the Eastern Mediterranean because prefer alkaline water environment which forms on the carbonates. During last year's we try to find new, unstudied aquatic objects in which can be identified charophyte algae. The most important localities can be found in the mountain areas because altitude play the major role in historical species diversity forming process (Barinova, 2011b) especially it can be interesting in the Upper Jordan River basin, which placed in two different slopes of the Jordan Rift Valley (Horowitz, 2001; Barinova and Nevo, 2010) as well as close related the Galilean Mountains. Our last experience shows that the diversity of this group of algae in Israel is still far from complete. Thus, we try to find new locality of charophytes and to study of community and the environment in which they are inhabit.

The bio-indication approach for ecological assessment of aquatic habitats in the Eastern Mediterranean is rather developed in Israel (Barinova, 2011a). We implemented of summarized information about species autecology (Van Dam et al., 1994; Barinova et al., 2006) for algal community from the Ga'aton River that is important monitoring object in the Lower Galilee.

The aim of present study is to describe of algae that studied firstly for the Ga'aton River in Israel, for characterize the river environment by bio-indication methods on the base of water chemistry and revealed diversity of algae and cyanobacteria.

\section{Material and Methods}

\subsection{Sampling and Laboratory Studies}

Material for this study comes from twenty one living and nineteen fixed algological samples, nine samples of charophytes and twelve samples of water that were collected during field trip in June 2012 and March 2015 in two stations of the Ga'aton River (Figure 1) in the Galilean mountains.

Algological samples were collected by scratching and water scooping, placed in $15 \mathrm{ml}$ plastic tubes, and partly fixed with $3 \%$ neutral formaldehyde solution, as well as partly not fixed and transported to the laboratory in the ice box. Charophyte samples were taken from the stream, placed to 3-liter plastic boxes, and transported to the laboratory in the ice box. Water samples were taken in 50-ml plastic tubes and transported to the lab in the ice box. 
Charophytes were treated with $2-3 \% \mathrm{HCl}$ to remove calcium carbonate. After washing several times with distilled water the material was studied with Nikon stereomicroscope with distilled water. The structure elements were observed with Nikon with digital camera, DinoLight camera, and light microscopes (LM) in the Institute of Evolution, University of Haifa and the Central Siberian Botanical Garden with help of international handbooks (Krause, 1997; John et al., 2011). Charophyte and microscopic algae abundance were assessed as abundance scores according 6-score scale (Barinova et al., 2006; Barinova, 2011a).

Algae and cyanobacteria were studied with the SWIFT and OLYMPUS dissecting microscopes under magnifications $740 \mathrm{x}-1000 \mathrm{x}$ from three repetitions of each sample and were photographed with OMAX Digital Camera A35100U. The diatoms were prepared by the peroxide technique (Swift, 1967) modified for glass slides (Barinova, 1997) and were placed in the Naphrax ${ }^{\circledR}$ mountain from two repetitions of each sample.

Temperature was measured with a thermometer. Water $\mathrm{pH}$, conductivity (EC), and TDS were measured with HANNA HI 9813-0. Measurements were made by adding the probe into the water till the reading was stabilized. The concentration of $\mathrm{N}-\mathrm{NO}_{3}$ was measured with HANNA HI 93728.

Periphyton from charophytes, as well as algal periphytonic samples was studied with help of international handbooks (Krause, 1997; Krammer and Lange-Bertalot, 1986, 1988, 1991; Komárek and Anagnostidis, 2005; Hofmann et al., 2011; John et al., 2011).

\subsection{Bio-indication and indices calculation}

The methods and indices that can be used for bio-indication of environment quality are based on the ecological point of view to the water and biota relationships (Barinova et al., 2006; Barinova, 2011a). The mutual influence of the diversity of freshwater algae and their habitat can be determined with the help of ecological preferences of the species developing in a studied community. This is a basic principle of bio-indication - compliance with the community composition to the parameters of its habitat.

Our ecological analysis has revealed a grouping of freshwater algae indicators to $\mathrm{pH}$, salinity, and saprobity as well as for other habitat conditions (Barinova et al., 2006; Barinova, 2011a). Each group was separately assessed in respect to its significance for bio-indication. Those species that predictably responded to environmental variables can be used as bio-indicators reflecting the response of aquatic ecosystems to eutrophication, $\mathrm{pH}$ levels, salinity, organic pollutions, nutrition type, and trophic level.

Index saprobity s was calculated according to (Sládeček, 1986). Index of aquatic ecosystem sustainable was calculated according to (Barinova et al., 2006; Barinova, 2011a) as (1):

$$
\text { WESI = Rank S / Rank N-NO } .
$$

Where: Rank S - rank of water quality on the Sladeček's indices of saprobity; Rank $\mathrm{N}-\mathrm{NO}_{3}-$ rank of water quality on the nitric-nitrogen concentration. 


\section{Macrothink}

Journal of Biology and Life Science

ISSN 2157-6076 2016, Vol. 7, No. 1

If WESI is equal to or larger than 1, the photosynthetic level is positively correlated with the level of nitrate concentration. If the WESI is less than 1, the photosynthesis is suppressed presumably according to toxic disturbance (Barinova et al., 2006; Barinova, 2011a).

\subsection{Description of Study Site}

The Ga'aton River is located in the Lower Galilee in the northern part of Israel (Figure 1). Stream is about $19 \mathrm{~km}$ in length, and flows from Moshav Meona until the Mediterranean Coast, next to Nahariya (Amiram et al., 1970). GPS coordinates of studied sites are $33^{\circ} 00^{\prime} 10^{\prime \prime} \mathrm{N}$ and $35^{\circ} 10^{\prime} 05^{\prime} \mathrm{E}$. Site altitude is fluctuated from about $165 \mathrm{~m}$ above sea level (a.s.l.) in site 1 (near the Ga'aton settlement) till $70 \mathrm{~m}$ a.s.l. in site 2 (near the Kabri settlement). The river is watered round the year (Figures 2,3) excluding low-storm discharge periods that happened few times per winter. Lots of water once flowed through this stream from the many springs that flow into it. Today most of the water is captured by Mekorot (Israel's national water company) and is used for the benefit of the nearby towns (http://www.snipview.com/q/Rivers_of_Israel).

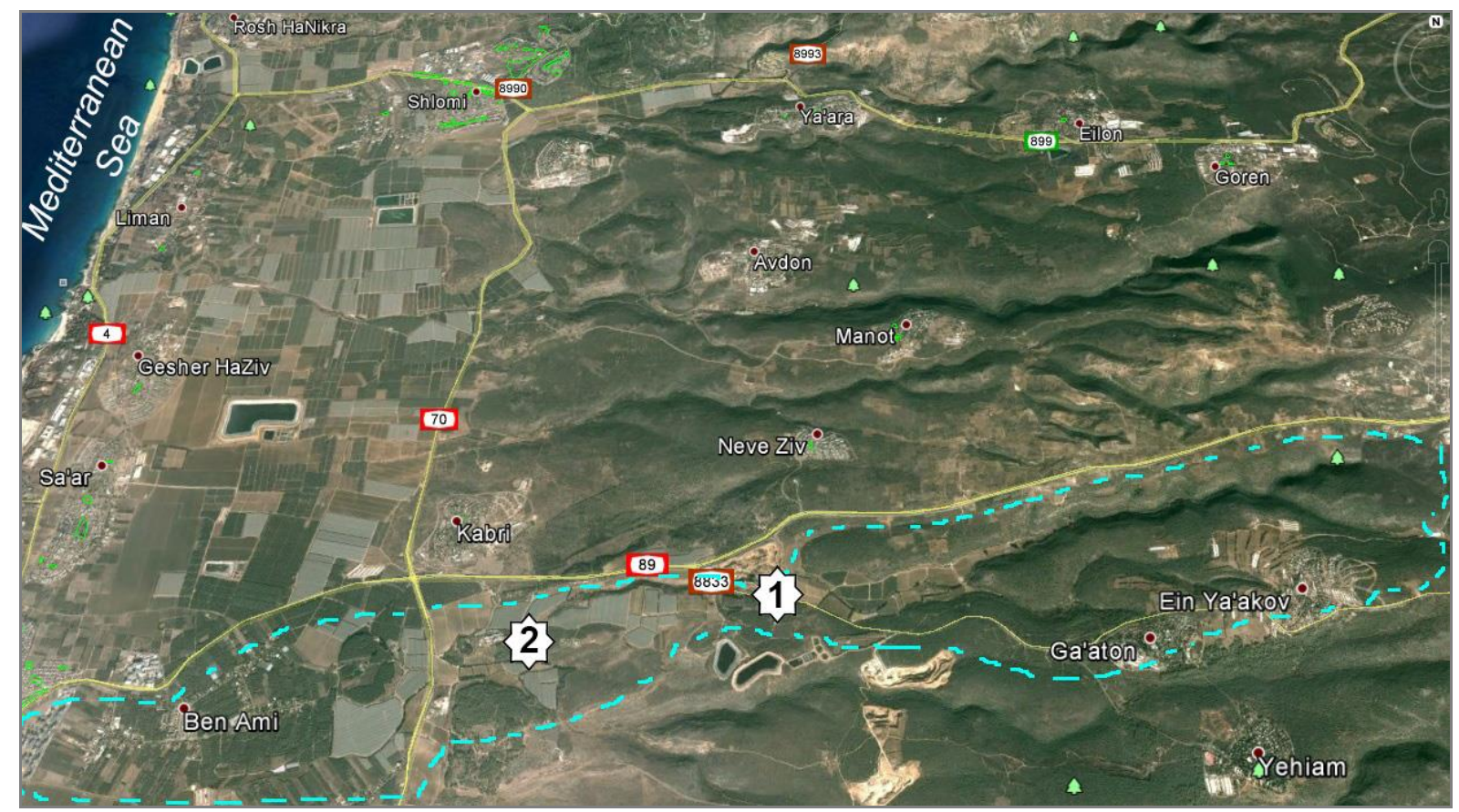

Figure 1. The Ga'aton River basin (blue dashed line) in the Lower Galilean Mountains with two study sites (white stars). 


\section{$\triangle$ Macrothink}

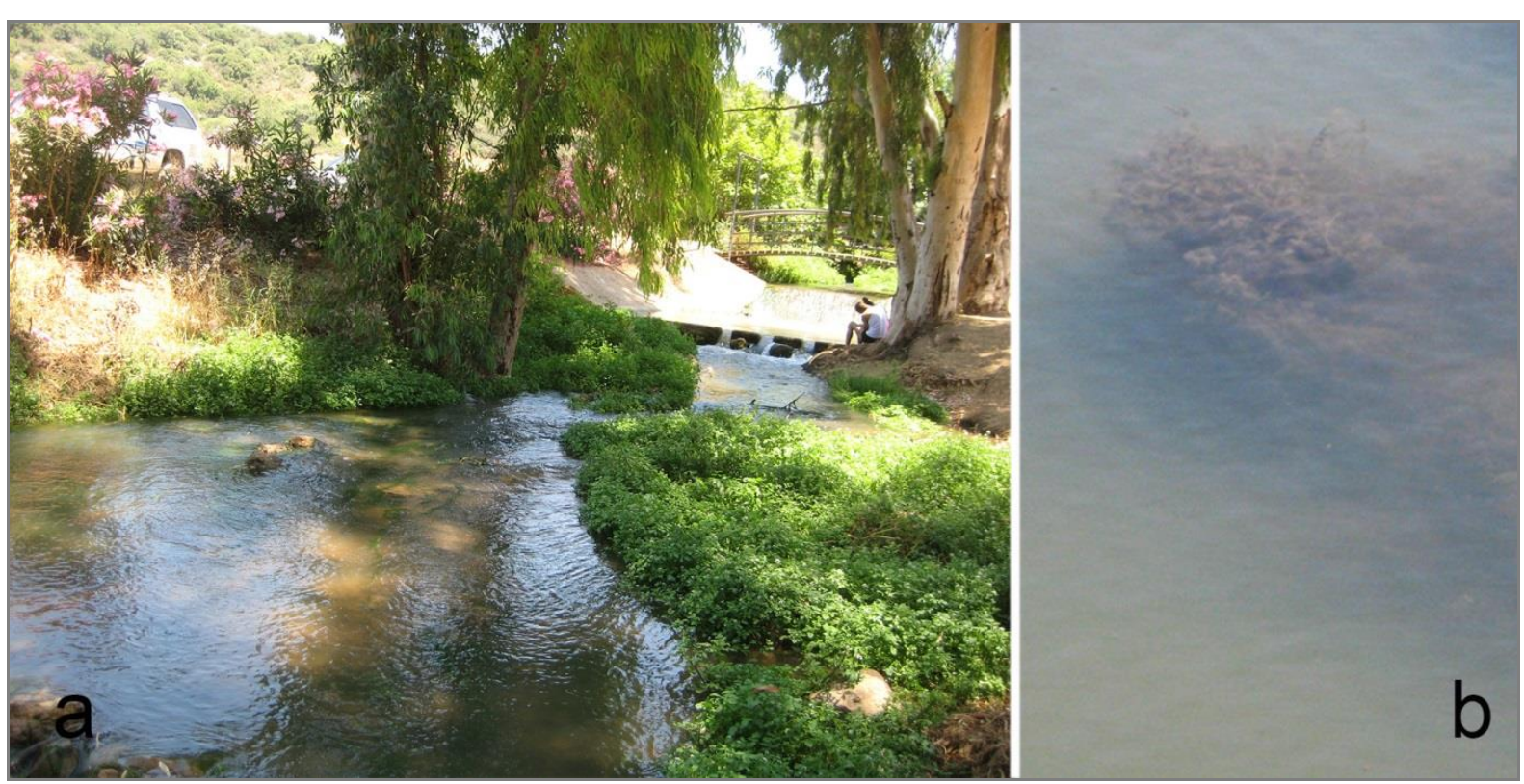

Figure 2. The Ga'aton River study site 1. Site view (a) and Chara grovesii massive grove (b)

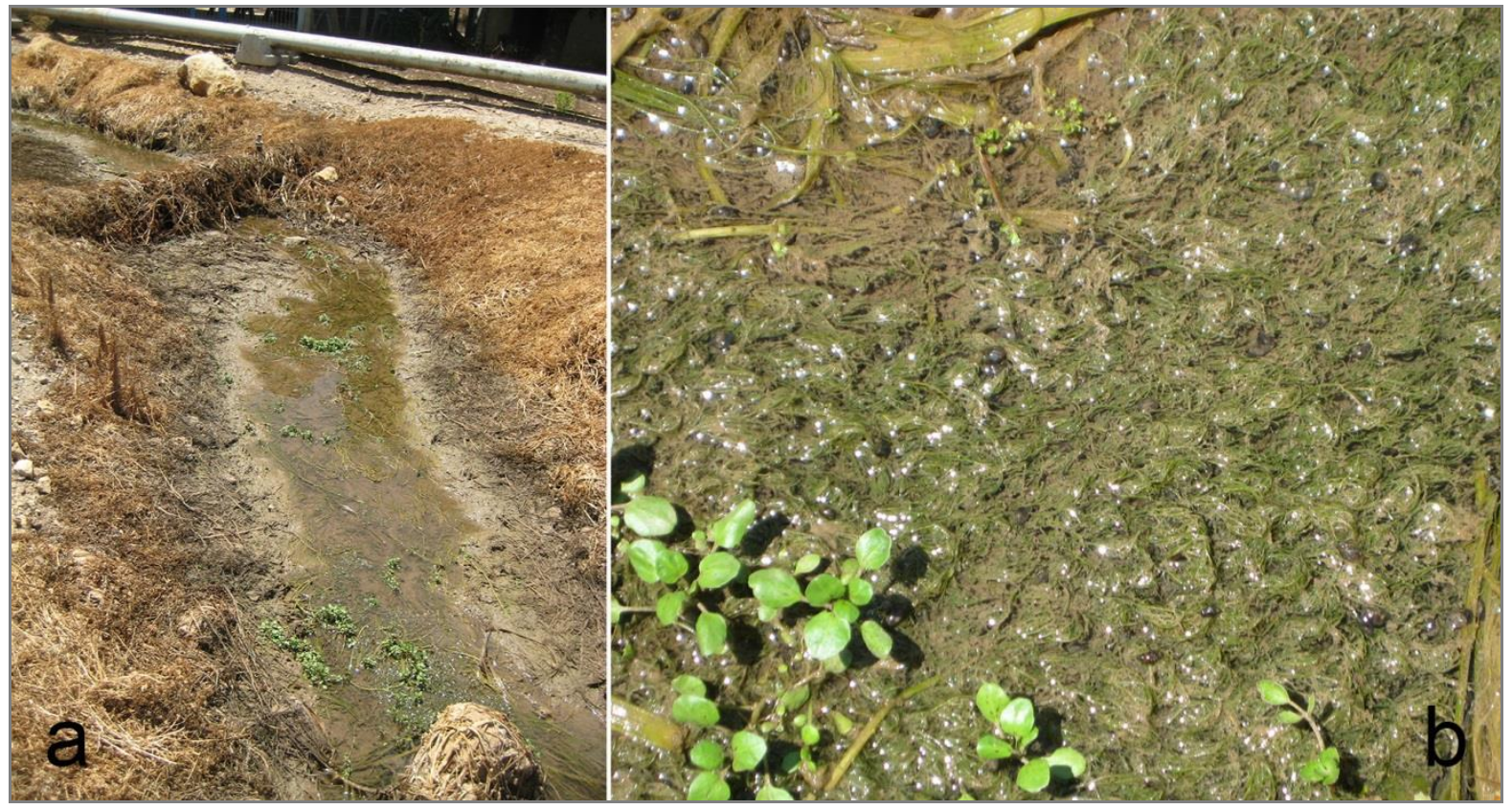

Figure 3. The Ga'aton River study site 2. Site view (a) and Chara grovesii massive grove (b)

The climate of the river Ga' aton basin is warm and temperate. In winter there is much more rainfall than in summer. The average annual temperature in Ga'aton is $19.5{ }^{\circ} \mathrm{C}$. The average annual rainfall is $703 \mathrm{~mm}$. The driest month is August with $0 \mathrm{~mm}$. Most precipitation falls in January, with an average of $192 \mathrm{~mm}$. The warmest month of the year is August with an average temperature of $26.3{ }^{\circ} \mathrm{C}$. In January, the average temperature is $12.4{ }^{\circ} \mathrm{C}$. It is the lowest average temperature of the whole year. The difference in precipitation between the driest month and the wettest month is $192 \mathrm{~mm}$. The average temperatures vary during the year by $13.9{ }^{\circ} \mathrm{C}$ (http://en.climate-data.org/location/201962/). 


\section{Results and Discussion}

\subsection{Chemical and Biological Data for the Ga'aton River Study Site}

Table 1 show that chemical variables in the Ga'aton River are fluctuated in the small range and reflects low mineralized fresh to slightly brackish low-alkaline water with low organic pollution. The major variables in sampling sites show increasing of water temperature and $\mathrm{pH}$ down the river.

Table 1. Averaged chemical and biological variables with Standard deviation in the Ga'aton River in 2012 and 2015

\begin{tabular}{|c|c|c|}
\hline Variable & St. 1 & St. 2 \\
\hline Coordinates, $\mathrm{N}$ & $33^{\circ} 00^{\prime} 897^{\prime \prime}$ & $33^{\circ} 00^{\prime} 92.3^{\prime \prime}$ \\
\hline Coordinates, $S$ & $35^{\circ} 10^{\prime} 838^{\prime \prime}$ & $35^{\circ} 09^{\prime} 00.7^{\prime \prime}$ \\
\hline Conductivity, $\mathrm{mS} \mathrm{cm}^{-1}$ & $0.526 \pm 0.01$ & $0.528 \pm 0.01$ \\
\hline TDS, $\mathrm{mg} \mathrm{l}^{-1}$ & $373.4 \pm 0.89$ & $370.8 \pm 0.45$ \\
\hline $\mathrm{N}-\mathrm{NO}_{3}, \mathrm{mg} \mathrm{l}^{-1}$ & $3.16 \pm 0.77$ & $2.48 \pm 0.38$ \\
\hline $\mathrm{pH}$ & $7.98 \pm 0.04$ & $8.02 \pm 0.08$ \\
\hline Temperature & $20.74 \pm 0.09$ & $30.12 \pm 0.08$ \\
\hline Index saprobity $S$ & $1.93 \pm 0.17$ & $1.83 \pm 0.21$ \\
\hline WESI & $0.50 \pm 0.07$ & $0.57 \pm 0.07$ \\
\hline No. of Species & $9 \pm 0$ & $17 \pm 0$ \\
\hline
\end{tabular}

The water conductivity and TDS are still in the same range, but nitric nitrogen decreased significantly and correlated with the same change in the index saprobity S. Index S decreased with small range fluctuation from 1.93 to 1.83 and still in the Water Quality Class III (Table 1). In the same time the species richness in algal community increased significantly from 9 to 17. This dynamic can be related with total changes of the stream environment as a result of seasonal watering fluctuation during the summer season. Site 2 is also under influence of small artificial pool the unavailable for sampling but algal diversity that comes from it is recognizable as increasing of green algae and cyanobacteria. In the same course is organic pollution utilization rate that reflects by Saprobity index S decreasing as a result of ecosystem activity in the site 2 .

\subsection{Diversity and Ecology of Algae}

We revealed 20 species from five taxonomic Divisions of algae and cyanobacteria including one of them macro-algae Chara grovesii (Table 2). Can be seen (Tables 1,2) that algal species richness in community was fluctuated significant over the sampling sites. Community was most represented by diatom algae with addition of greens and cyanobacteria, and one euglenoid species. Studied stream is only two localities occupied by charophytes. The stream bottom was covered by bushes of macrophyte alga Chara grovesii in the site 1 (Figures 2,4) in the part of the river channel with weak currents together with green alga Cladophora glomerata and attached diatoms.

Table 2. Diversity of algae in the charophyte communities of the Ga'aton River with 
abundance scores and species autecology (according to Van Dam et al., 1994 and Barinova et al., 2006). Ecological types (Sub): B, benthic; P-B, planktonic-benthic. Temperature (T): temp, temperate waters inhabitant; eterm, eurythermic inhabitant. Streaming and Oxygenation (Oxy): str, streaming waters inhabitant; st-str, low streaming waters inhabitant; st, standing waters inhabitant. Acidity $(\mathrm{pH})$ : ind, indifferent; alf, alkaliphil. Halobity (Sal): i, oligohalobious-indifferent; hl, oligohalobious-halophilous. Saprobity (D): es, eurysaprob; sx, saproxen; sp, saprophil. Saprobity (Sap): o, oligosaprob; x-o, xeno-oligosaprob; o-x, oligo-xeno-saprob; b, betamesosaprob; b-o, beta-oligosaprob; o-b, oligo-beta-mesosaprob; $a-b$, alpha-beta-mesosaprob; b-a, beta-alpha-mesosaprob; $x$, xenosaprob. Nitrogen uptake metabolism (Aut-Het): ats, nitrogen-autotrophic taxa, tolerating very small concentrations of organically bound nitrogen; ate, nitrogen-autotrophic taxa, tolerating elevated concentrations of organically bound nitrogen; hne, facultatively nitrogen-heterotrophic taxa, needing periodically elevated concentrations of organically bound nitrogen; hce, obligately nitropgen-heterotrophic taxa, needing continuously elevated concentrations of organically bound nitrogen. Trophic state (Tro): e, eutraphentic; o-e, oligo- to eutraphntic (hypereutraphentic); he, hypereutraphentic. Species-specific index saprobity s (s).

\begin{tabular}{|c|c|c|c|c|c|c|c|c|c|c|c|c|c|}
\hline Taxa & St. 1 & St. 2 & Sub & $\mathrm{T}$ & Oxy & $\mathrm{pH}$ & Sal & Sap & $\mathrm{D}$ & $\begin{array}{l}\text { Aut- } \\
\text { Het }\end{array}$ & Tro & $\begin{array}{c}\mathrm{pH} \\
\text { range }\end{array}$ & s \\
\hline \multicolumn{14}{|l|}{ Cyanobacteria } \\
\hline $\begin{array}{l}\text { Merismopedia hyalina } \\
\text { (Ehrenberg) Kützing }\end{array}$ & 0 & 2 & $\mathrm{P}$ & - & - & - & - & - & - & me & - & - & - \\
\hline Oscillatoria sp. & 0 & 2 & - & - & - & - & - & - & - & - & - & - & - \\
\hline \multicolumn{14}{|l|}{ Euglenozoa } \\
\hline $\begin{array}{l}\text { Trachelomonas volvocina } \\
\text { (Ehrenberg) } \\
\text { Ehrenberg }\end{array}$ & 0 & 1 & B & eterm & st-str & ind & $\mathrm{i}$ & $\mathrm{b}$ & - & - & - & $4.4-8.4$ & 2.0 \\
\hline \multicolumn{14}{|l|}{ Bacillariophyta } \\
\hline $\begin{array}{l}\text { Achnanthidium } \\
\text { minutissimum (Kützing) } \\
\text { Czarnecki }\end{array}$ & 2 & 2 & B & eterm & st-str & alf & $\mathrm{i}$ & $\mathrm{b}$ & es & ate & o-e & $4.3-9.2$ & 1.2 \\
\hline $\begin{array}{l}\text { Amphora ovalis (Kützing) } \\
\text { Kützing }\end{array}$ & 0 & 2 & B & temp & st-str & alf & $\mathrm{i}$ & $a-b$ & sx & ate & $\mathrm{e}$ & $6.2-9.0$ & 1.5 \\
\hline $\begin{array}{l}\text { Cylindrotheca gracilis } \\
\text { (Brébisson ex } \\
\text { Kützing) Grunow }\end{array}$ & 0 & 1 & B & - & st & - & hl & o & - & - & $\mathrm{e}$ & - & 2.8 \\
\hline $\begin{array}{l}\text { Gomphonema parvulum } \\
\text { (Kützing) Kützing }\end{array}$ & 0 & 1 & B & temp & str & ind & $\mathrm{i}$ & $\mathrm{x}$ & es & hne & $\mathrm{e}$ & 4.5 & 2.3 \\
\hline Navicula exigua Gregory & 4 & 3 & $\mathrm{~B}$ & - & str & alf & $\mathrm{i}$ & $\mathrm{x}-\mathrm{O}$ & es & ats & $\mathrm{e}$ & - & 1.4 \\
\hline $\begin{array}{l}\text { Nitzschia palea (Kützing) } \\
\text { W.Smith }\end{array}$ & 2 & 2 & P-B & temp & - & ind & $\mathrm{i}$ & $\mathrm{o}-\mathrm{x}$ & $\mathrm{sp}$ & hce & he & $7.0-9.0$ & 2.8 \\
\hline $\begin{array}{ll}\text { Navicula } & \text { tripunctata } \\
\text { (O.F.Müller) } & \\
\end{array}$ & 4 & 2 & B & - & st-str & ind & $\mathrm{i}$ & $\mathrm{b}$ & es & ate & $\mathrm{e}$ & - & 1.7 \\
\hline
\end{tabular}




\begin{tabular}{|c|c|c|c|c|c|c|c|c|c|c|c|c|c|}
\hline Bory de Saint-Vincent & & & & & & & & & & & & & \\
\hline $\begin{array}{l}\text { Nitzschia tryblionella } \\
\text { Hantzsch }\end{array}$ & 3 & 0 & B & - & st-str & alf & hl & $\mathrm{O}$ & - & ate & $\mathrm{e}$ & - & 2.6 \\
\hline $\begin{array}{l}\text { Rhoicosphenia } \\
\text { abbreviata } \\
\text { (C.Agardh) } \\
\text { Lange-Bertalot }\end{array}$ & 1 & 0 & P-B & - & st-str & alf & $\mathrm{i}$ & $\mathrm{X}-\mathrm{O}$ & es & ate & $\mathrm{e}$ & 6.7 & 1.9 \\
\hline $\begin{array}{l}\text { Ulnaria ulna (Nitzsch) } \\
\text { P.Compère }\end{array}$ & 2 & 0 & B & temp & st-str & alf & $\mathrm{i}$ & b-o & es & ate & o-e & $5.0-9.2$ & 2.3 \\
\hline Chlorophyta & & & & & & & & & & & & & \\
\hline $\begin{array}{l}\text { Cladophora glomerata } \\
\text { (Linnaeus) Kützing }\end{array}$ & 4 & 3 & P-B & - & st-str & alf & $\mathrm{i}$ & $b-o$ & - & - & - & $7.5-8.5$ & - \\
\hline $\begin{array}{l}\text { Scenedesmus obtusus } \\
\text { Meyen }\end{array}$ & 0 & 1 & P-B & - & st-str & - & - & b & - & - & - & - & 1.8 \\
\hline $\begin{array}{l}\text { Monoraphidium obtusum } \\
\text { (Korshikov) } \\
\text { Komárková-Legnerová }\end{array}$ & 0 & 3 & P-B & - & st-str & - & - & o & - & - & - & - & 1.5 \\
\hline $\begin{array}{l}\text { Monoraphidium griffithii } \\
\text { (Berkeley) } \\
\text { Komárková-Legnerová }\end{array}$ & 0 & 2 & P-B & - & st-str & - & - & b & - & - & - & - & 2.2 \\
\hline $\begin{array}{l}\text { Scenedesmus armatus } \\
\text { (R.Chodat) R.Chodat }\end{array}$ & 0 & 1 & P-B & - & st-str & - & - & $\mathrm{o}-\mathrm{a}$ & - & - & - & - & 2.2 \\
\hline $\begin{array}{l}\text { Kirchneriella obesa } \\
\text { (West) West \& G.S.West }\end{array}$ & 0 & 2 & P-B & - & st-str & - & $\mathrm{i}$ & $\mathrm{b}$ & - & - & - & - & 1.8 \\
\hline Charophyta & & & & & & & & & & & & & \\
\hline Chara grovesii B.P. Pal & 6 & 6 & B & - & - & - & - & - & - & - & - & - & - \\
\hline
\end{tabular}

Community in the site 2 (Figures 3, 5) was significantly changed and enriched till 17 species by green algae Monoraphidium and Kirchneriella as well as cyanobacteria species (Table 2) that usually occupied small pools.

The most remarkable species that occupied both studied sites was Chara grovesii (C. vulgaris L. var. gymnophylla (A. Braun) Nym. f. grovesii (B.P. Pal) R.D. Wood). Species structural elements and thallus habitat show (Figures 4, 5), that our samples are in the ranks of $C$. gymnophylla A. Braun concept uniting gymnophyllous forms with diplostichous aulocanthous, isostichous and even tylacanthous stem cortex (Krause, 1997). Possibly this is consequence of W. Krause point of view about conspecificity of $C$. gymnophylla with aulocanthous to isostichous stem cortex and C. conimbrigensis da Cunha (C. vulgaris var. gymnophylla f. conimbrigensis (da Cunha) R.D. Wood) with tylacanthous cortex. The latter taxon was described from Portugal (da Cunha, cit. in: Wood and Imahori, 1965) and later reported from Spain (Sanchez, 1984), Macedonia and Croatia (Blaženčić et al., 2006). This moss-like growth form is typical for groundwater outlets, where the shoots protruding from the water surface without drying up (Krause, 1997). This is dissimilar with locality studied. 


\section{Macrothink}

Chara conimbrigensis has small thalli which are bushy and condensed at least in upper parts, and tylacanthous stem cortex (Wood and Imahori, 1965: icon 34). The latter type of cortex was characteristic for specimens studied in contrast with habit. Therefore they were better corresponding to C. grovesii described from Myanmar (Pal, 1932; Wood and Imahori, 1964, 1965) and found in China and Iran (Chen et al., 1988; Han and Li, 1994; Ahmadi et al, 2012). Noteworthy the Iranian specimens differed from species diagnosis by presence of single basal corticated segment within a branchlet. Our finding is a new species record for Israel and Mediterranean region. Previously we revealed that in Israeli populations of charophytes species is simply separated from the other members of the genus Chara by AFLP analysis (Yehuda et al., 2013) including C. gymnophylla from the Dan River, the Upper Jordan River tributary.

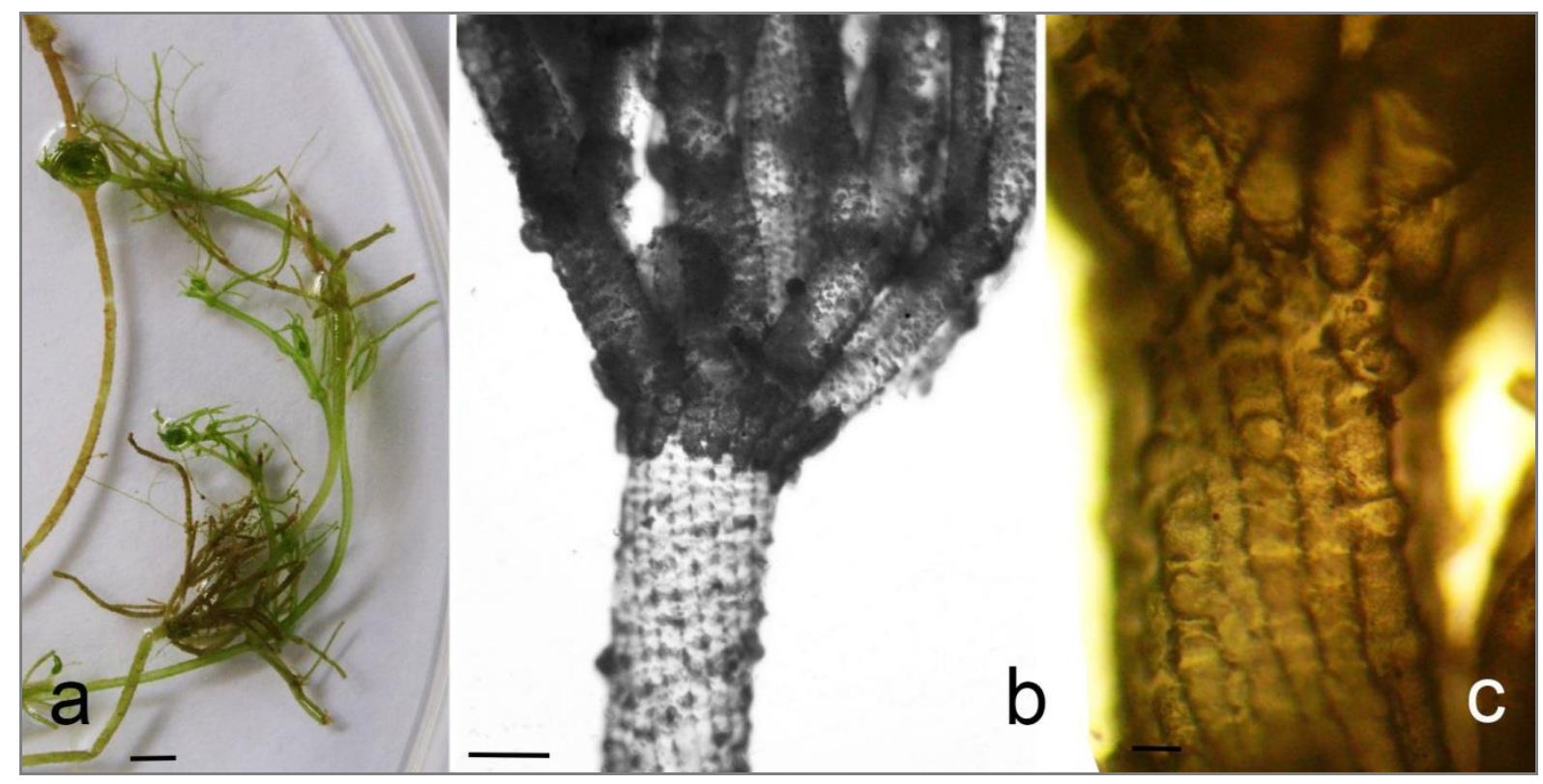

Figure 4. Chara grovesii in the Ga'aton River site 1. Total view of thallus (a), axis with stipulodes and base of whorl (b), apical part of axis with axial cortex (c). Scale bar: a $-1 \mathrm{~mm}$, $\mathrm{b}-100 \mu \mathrm{m}, \mathrm{c}-10 \mu \mathrm{m}$. 


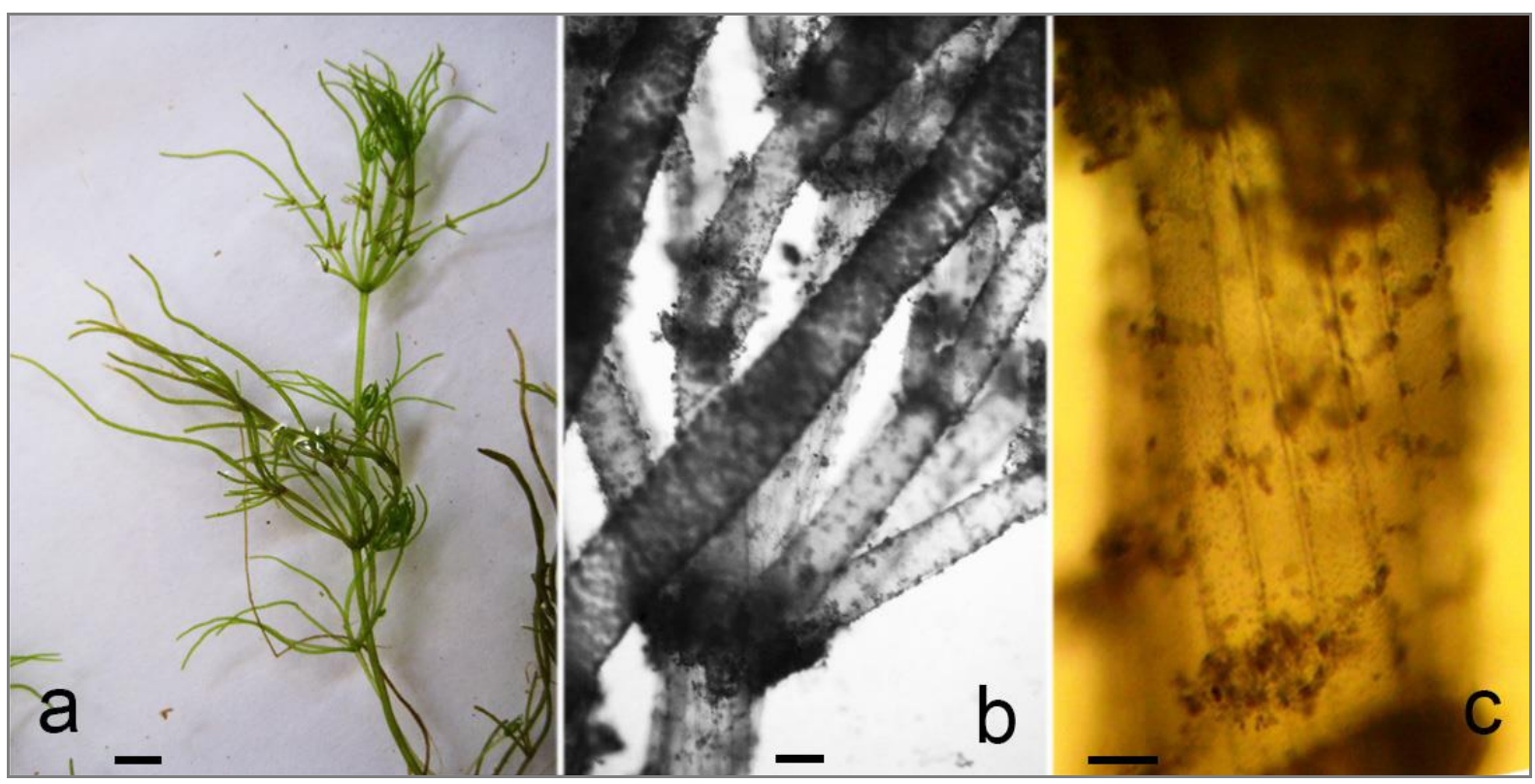

Figure 5. Chara grovesii in the Ga'aton River site 2. Total view of thallus (a), axis with stipulodes and base of whorl (b), axis with axial cortex (c). Scale bar: $\mathrm{a}-1 \mathrm{~mm}, \mathrm{~b}-50 \mu \mathrm{m}, \mathrm{c}$ $-20 \mu \mathrm{m}$.

The macro-alga Chara grovesii community in the Ga'aton River was dominated by diatoms (Table 2) that attach of macro-alga as well as submerged stones and plants in the stream. Dynamic of species percentage in Divisional level show that site community is strongly followed to domination of diatoms in site 1 during study period (Figure 6) whereas is enriched by greens in site 2. The same tendency we found in abundance of species (Figure 6). That means that community structure was dramatically changed from diatom dominated to diatom-greens.
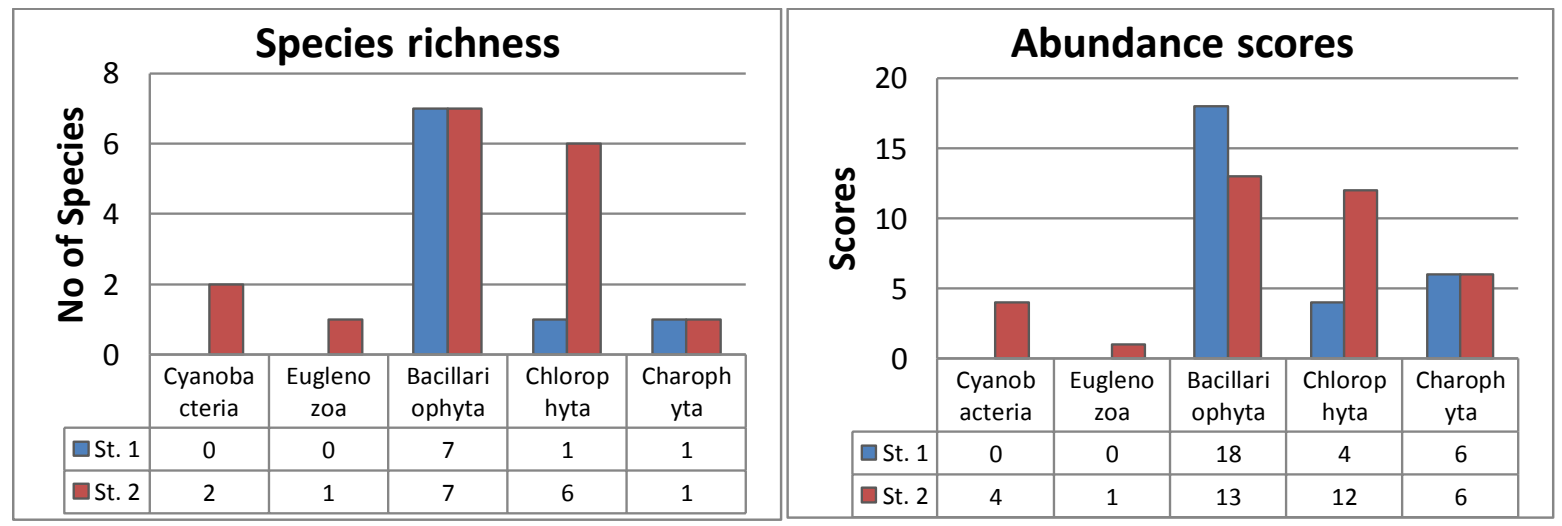

Figure 6. Dynamics of algal species richness and abundance in communities of the Ga'aton River sites

During our previous visits in 2004-2010 to the Ga'aton River we don't find the cahrophytes. Earlier we found that periodical desiccation is caused the charophyte plants extinction, but they can be renewed after few years dry period as we explore in other charophyte sites (Barinova and Romanov, 2014b). We assume that renewing of C. grovesii in this site can be 
possible with oospores storage in the stream sediments. It is very important that studied population of Chara demonstrated high tolerance to low-storm discharge as bearing on ecological consequences of climate change (Barinova et al., 2010) in region under climate change coming (Perry and Perry, 1989).

\subsection{Bio-Indication of the Ga'aton River Environment}

We use bio-indication methods on the base of ecology of algal species which inhabiting the river water and substrates in purpose to characterize of the water quality in which Chara grovesii is able to grow.

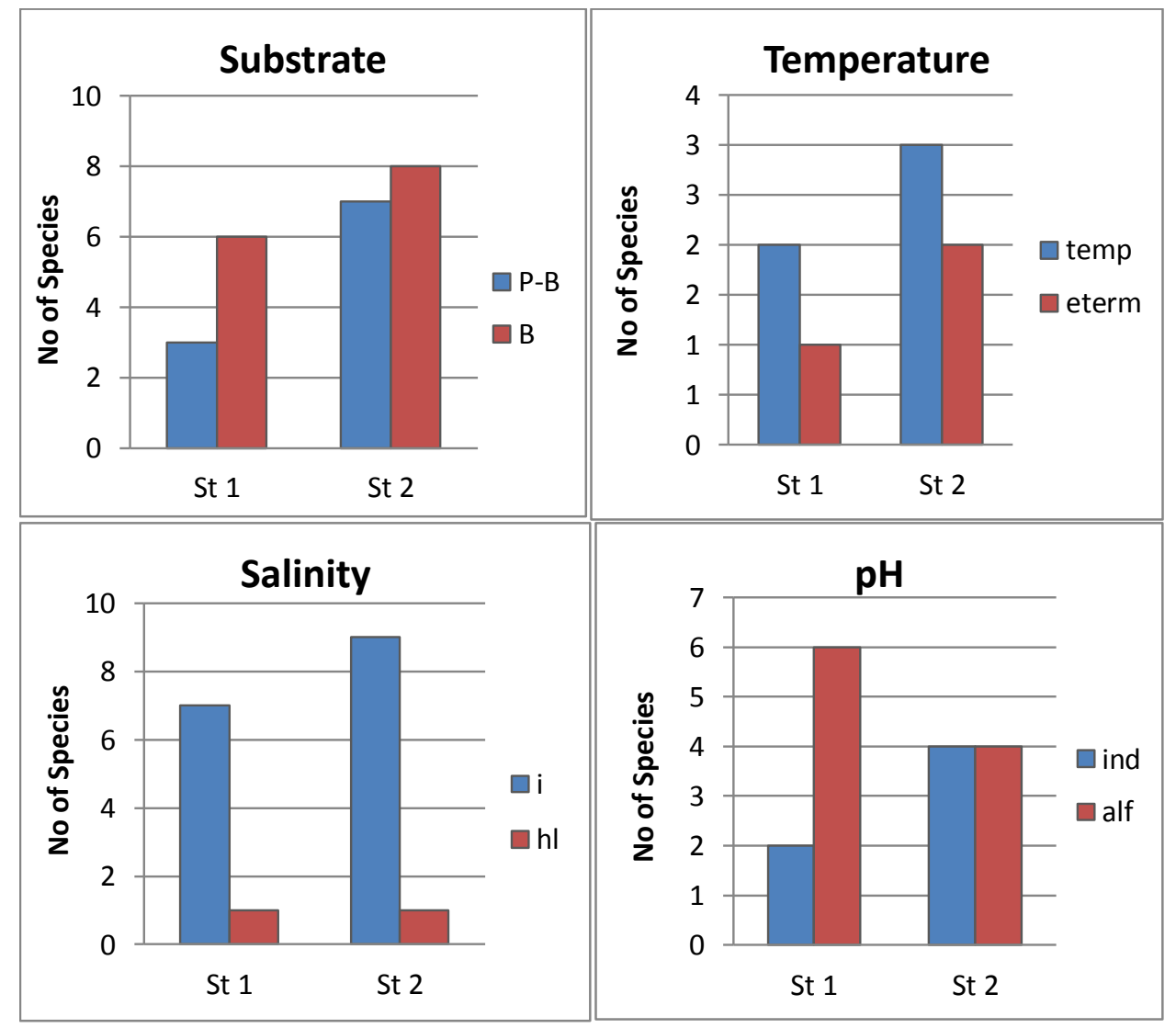

Figure 7. Bio-indication plots of the Ga'aton River water on the base of algal community. Ecological groups are arranged in order of parameter increasing, abbreviation given as in Table 2

As a result of bio-indication (Table 2), we found that diatoms, greens, and charophyte algae, and cyanobacteria are characterize the environment as temperate, low alkaline, middle oxygenated fresh waters with low to middle organic pollution. As can be seen in Table 2 and Figures 7-9, algal species survived mostly as benthic forms that increased in percentage, but plankto-benthic life still also presented. The stream water is temperate in temperature, alkaline, and fresh (Figure 8). Algal ecology reflects intermediate organic pollution according the Watanabe system (Figure 8) and Class of Water Quality II-III according to Sládeček (1973) system (Figure 9). Algae in the Ga'aton River community preferred photosynthetic way of nutrition indicators of which decreased down the river (Figure 8). Indicators of 


\section{Macrothink}

trophic state of stream ecosystem show prevailing of eutraphentic species but diversity of high trophic state groups decreased down the river with tendency of eutrophication decreasing (Figure 8).

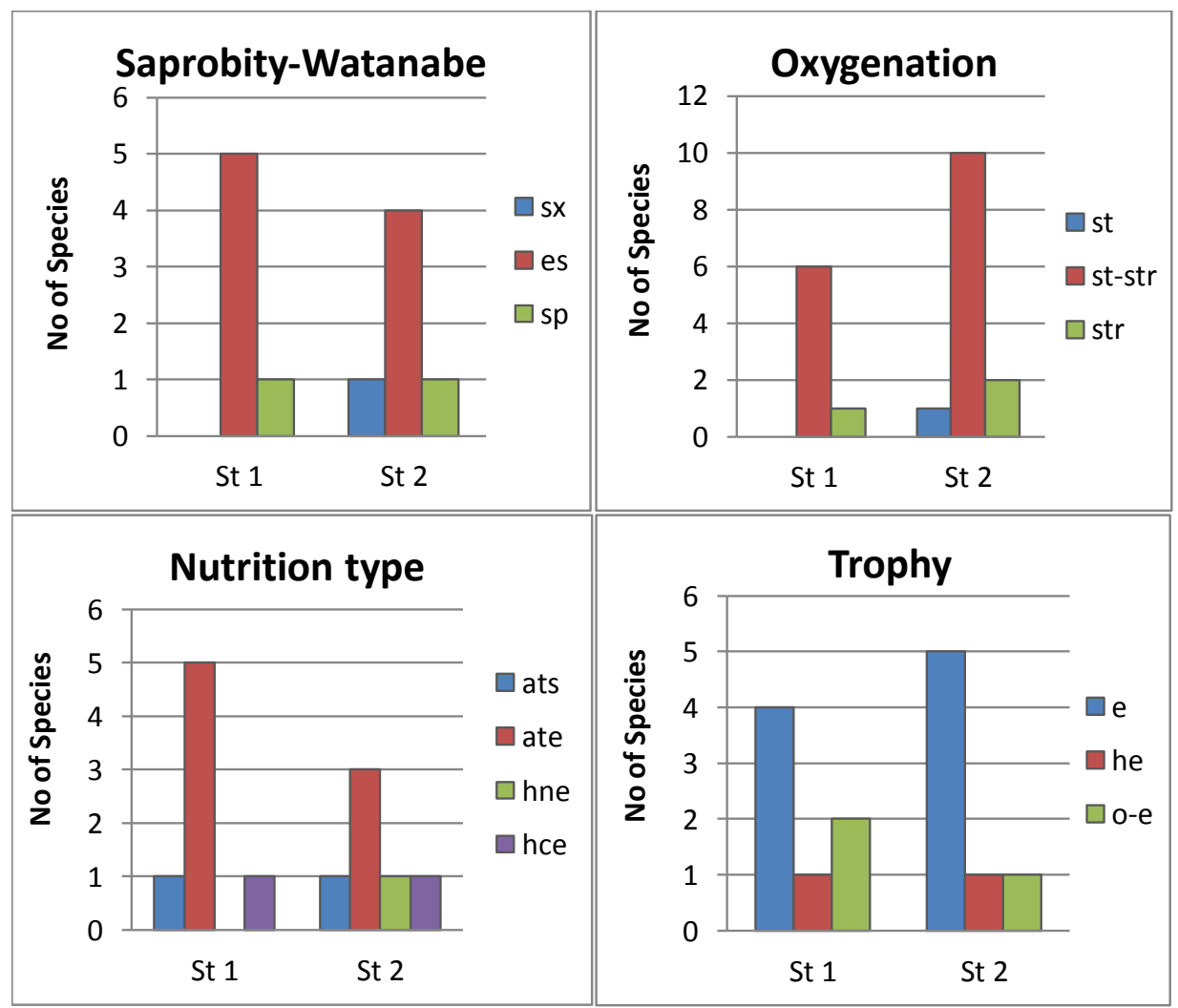

Figure 8. Bio-indication plots of the Ga'aton River water on the base of algal community. Ecological groups are arranged in order of parameter increasing, abbreviation given as in Table 2

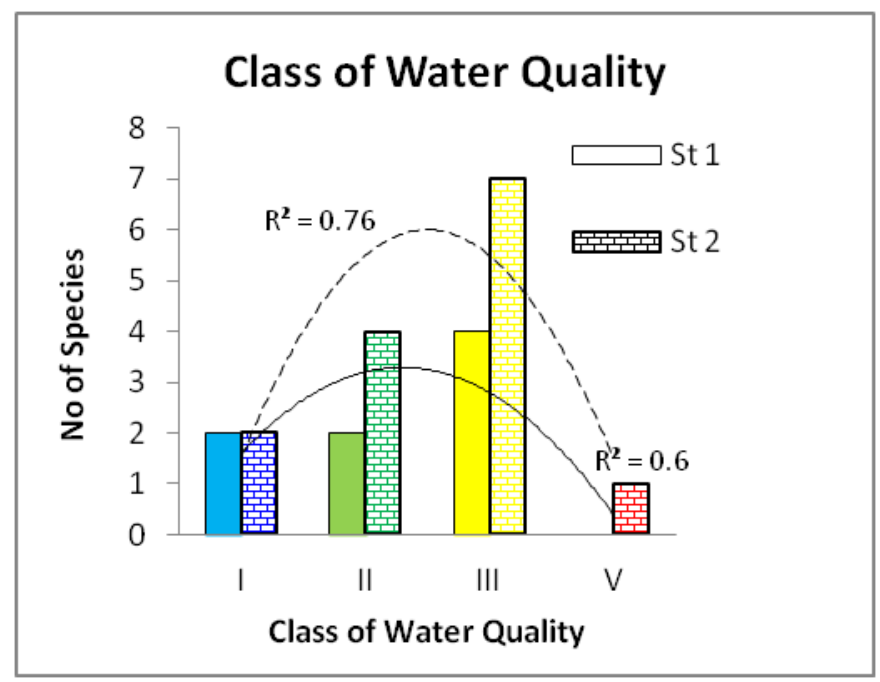

Figure 9. Bio-indication plot of the Ga'aton River water on the base of algal community. Water Quality Classes indicators are given in EU color code 
Species-specific index of saprobity of algal species fluctuated from 1.2 to 2.8 (Table 2), but calculated community index $\mathrm{S}$ changed from 1.93 in the site 1 to 1.83 in the site 2 (Table 2) with average decreasing down the river. Index of saprobity $S$ reflects of Water Quality Class III that confirms our bio-indication results (Figure 9) on the base of saprobity indicators groups (Table 2). Trend lines on the Figure 9 histograms show that water quality in the both sites is similar and satisfactory because summit of the trend line slightly moved from Class III to Class II.

Pollution state of the studied river can be recognized with Index WESI calculation. Table 1 shows that WESI in the both sites is lower than 1.0. It can be related with impacted photosynthesis by diverse pollutants. But can be seen that index slightly increased down the river from 0.50 to 0.57 that show tendency of pollution decreasing as a result of the self-purification process in the river ecosystem.

\section{Conclusion}

The Ga'aton River represents a natural ecosystem which is formed by diverse algae and still under anthropogenic press. It is the first study of new locality with charophytes algae in semi-arid to temperate climate region of Israel, the Lower Galilee. Studied community of the Ga'aton River included 20 species from five taxonomic Divisions of algae and cyanobacteria including one of them macro-algae Chara grovesii, with diatoms prevailing. Most abundant of them was green alga Cladophora glomerata that inhabit site 1 together with Chara grovesii. Later community was dramatically changed under influence that comes from the small pool, with increasing of greens such as Monoraphidium and Kirchneriella species, and diatoms as Navicula exigua. Charophytes has been find only once during few field trips but in other time it take away and we only can hope that can renewed with oospores storage in the stream sediments. We characterize the Ga'aton River sites with help of bio-indication and water chemical variables. The charophyte studied sites can be assessed as fresh, low alkaline, low to middle organic polluted with mainly eutrophic state. Saprobity index $\mathrm{S}$ that reflect organic pollution impact is fluctuated in small range (1.83-1.93) and reflect low to middle organic pollution rate and Water Quality Class III. Aquatic Ecosystem State Index WESI demonstrated pollution impact to photosynthesis. Both indices show pollution decreasing down the river as a result of self-purification.

We can to conclude that as a result of present initial study the Ga'aton River sites can be recommended for regularly monitoring of chemical and biological variables in purpose the watershed management and protection.

\section{Acknowledgement}

This work is partly funded by the Israeli Ministry of Absorption, Israeli Taxonomic Initiative Fond, and the Russian Foundation for Basic Research, project 14-04-31596-mol-a.

\section{References}

Amiram, D. H. K., Rosenan, N., Kadmon, N., Elster, J., Gilead, M., \& Paran, U. (eds.). (1970). Atlas of Israel. Amsterdam: Ministry of Labour, Jerusalem, and Elsevier Publishing 
Co.

Barinova, S., \& Romanov, R. (2014a). A new Chara locality in the protected area of the Galilee Mountains, Israel. Natural Resources and Conservation, 2(5), 80-85. DOI: 10.13189/nrc.2014.020502

Barinova S., \& Romanov, R. (2014b). Unique locality with charophytes in the Mount Arbel National Park, Israel. Elixir Bio Diversity, 77, 28932-28936. Available: www.elixirpublishers.com.

Barinova, S., \& Romanov, R. (2015a). Charophyte community in the lowermost locality in the world near Dead Sea, Israel. International Journal of Plant and Soil Science, 6(4), 229-243. http://dx.doi.org/10.9734/IJPSS/2015/16063

Barinova, S., \& Romanov, R. (2015b). How a new locality of algal community with charophytes in the Negev Desert, Israel, was formed. Expert Opinion on Environmental Biology, 4(2), 1-7. http://dx.doi.org/10.4172/2325-9655.1000116

Barinova, S., \& Romanov, R. (2015c). The Charophytes (Charophyta) Locality in the Milkha Stream, Lower Jordan, Israel. Natural Resources and Conservation, 3(2), 19-30. DOI: 10.13189/nrc.2015.030201.

Barinova, S. (2011a). Algal diversity dynamics, ecological assessment, and monitoring in the river ecosystems of the eastern Mediterranean. New York: Nova Science Publishers, USA.

Barinova, S. (2011b).The effect of altitude on distribution of freshwater algae in continental Israel. Current Topics in Plant Biology, 12, 89-95.

Barinova, S.S. \& Nevo, E. (2010). The Upper Jordan River algal communities are evidence of long-term climatic and anthropogenic impacts. Journal of Water Resource and Protection, 2, 507-526. http://dx.doi.org/10.4236/jwarp.2010.26058

Barinova, S. S. (1997). Morphology of connective spines in diatom algae of the genus Aulacoseira Thwaites. Paleontological Journal, 31(2), 239-245.

Barinova, S. S., Medvedeva, L. A. \& Anissimova, O. V. (2006). Diversity of algal indicators in environmental assessment. Tel Aviv: Pilies Studio. (In Russian).

Barinova, S. S., Yehuda, G., \& Nevo, E. (2010). Comparative analysis of algal communities of northern and southern Israel as bearing on ecological consequences of climate change. Journal of Arid Environments, 74, 765-776. http://dx.doi.org/10.1016/j.jaridenv.2009.03.001

Blaženčić, J., Stevanović, B., Blaženčić, Z., \& Stevanović, V. (2006). Red Data List of charophytes in the Balkans. Biodiversity and Conservation, 15, 3445-3457. http://dx.doi.org/10.1007/s10531-005-2008-5

Chen, X. Q., Liu, L., Zhu, H., \& Guo, H.S. (1988). Some new taxa and records of Characeae in Hunan, China. Acta Phytotaxonomica Sinica, 26(6), 467-482. (In Chinese with Abstract and Tables in English). 
Han, F. S., \& Li, Y. Y. (eds.). (1994). Charophyta. Tomus 3. Flora algarum sinicarum aquae dulcis / Consilio Florarum Cryptogamarum Sinicarum Academiae Sinicae edita, 1-267. Beijing: Science Press. (In Chinese).

Hofmann, G., Werum, M., \& Lange-Bertalot, H. (2011). Diatomeen im Süßwasser-Benthos von Mitteleuropa. Ruggell: A.R.G. Gantner Verlag K.G.

Horowitz, A. (2001). The Jordan Rift Valley. Exton: A.A. Balkema Publishers, Lisse, PA. http://dx.doi.org/10.1201/9781439834244

John, D. M., Whitton, B. A. \& Brook, A. J. (eds.). (2011). The freshwater algal flora of the British Isles: an identification guide to freshwater and terrestrial algae. Cambridge: Pages Cambridge University Press.

Komárek, J., \& Anagnostidis, K. (2005). Cyanoprokaryota. Teil 2: Oscillatoriales. In: B. Büdel, G. Gärtner, L. Krienitz \& M. Schagerl (eds.), Süsswasserflora von Mitteleuropa 19/2, 1-759. München: Elsevier.

Krammer, K., \& Lange-Bertalot, H. (1986). Bacillariophyceae, 1. Teil: Naviculaceae. In: H. Ettl, J. Gerloff, H. Heynig \& D. Mollenhaues (eds.), Süßwasserflora von Mitteleuropa, 2(1), 1-876. Stuttgart, New York: G. Fischer Verlag.

Krammer, K., \& Lange-Bertalot, H. (1988). Bacillariophyceae, 2. Teil: Bacillariaceae, Epithemiaceae, Surirellaceae. In: H. Ettl, J., Gerloff, H. Heynig \& D. Mollenhaues (eds.), Süßwasserflora von Mitteleuropa. 2(2), 1-596. Stuttgart, New York: G. Fischer Verlag.

Krammer, K., \& Lange-Bertalot, H. (1991). Bacillariophyceae, 4. Teil: Achnanthaceae. Kritische Erganzungen $\mathrm{zu}$ Navicula (Lineolatae) und Gomphonema, Gesamtliteraturverzeichnis. In: H. Ettl, J. Gerloff, H. Heynig \& D. Mollenhaues (eds.), Süßwasserflora von Mitteleuropa, 2(4), 1-437. Stuttgart, New York: G. Fischer Verlag.

Krause, W. (1997). Charales (Charophyceae). In: H. Ettl, G. Gärtner, H. Heynig \& D. Mollenhauer (eds.), Süßwasserflora von Mitteleuropa, 18, 1-202. Jena, Stuttgart, Lubeck, Ulm: Gustav Fischer Verlag.

Pal, B.P. (1932). Burmese Charophyta. Journal of the Linnean Society of London, Botany, 49(327), 47-92. http://dx.doi.org/10.1111/j.1095-8339.1932.tb00382.x

Perry, A. S., \& Perry, R. Y. (1989). Effects in arid regions. In: Ecotoxicology and Climate, SCOPE, Published by John Wiley and Sons Ltd.

Rayss, T. (1951). Les algues des eaux continentals, Matériaux pour la flore algologique de la Palestine. Palestinian Journal of Botany, 5, 71-95.

Romanov, R.E. \& Barinova, S.S. (2012). The charophytes of Israel: historical and contemporary species richness, distribution, and ecology. Biodiversity: Research and Conservation, 25, 57-64. http://dx.doi.org/10.2478/v10119-012-0015-4

Romanov, R. E., Gontcharov, A. A., \& Barinova, S. S. (2015). Chara globata Mig. (Streptophyta: Charales): rare species revised. Fottea, Olomouc, 15(1), 39-50. 
http://dx.doi.org/10.5507/fot.2015.004

Sanchez, P. M. (1984). Contribucion al conocimiento del genero Chara en Andalucia. Acta Botánica Malacitana, 9, 79-84. Available: http://hdl.handle.net/10630/3633\#sthash.Q4OQ2vyw.dpuf

Sládeček, V. (1973). System of water quality from the biological point of view. Ergebnisse der Limnologie, 7, 1-128.

Sládeček, V. (1986). Diatoms as indicators of organic pollution. Acta Hydrochimica and Hydrobiologica, 14, 555-566. http://dx.doi.org/10.1002/aheh.19860140519

Swift, E. (1967).Cleaning Diatom Frustules with Ultraviolet Radiation and Peroxide. Phycologia, 6(2-3), 161-163. http://dx.doi.org/10.2216/i0031-8884-6-2-161.1

Van Dam, H., Mertens, A., \& Sinkeldam, J. (1994). A coded checklist and ecological indicator values of freshwater diatoms from The Netherlands. Netherlands Journal of Aquatic Ecology, 28, 117-133. http://dx.doi.org/10.1007/BF02334251

Wood, R., D. \& Imahori, K. (1964). A revision of the Characeae. II. Iconograph of the Characeae, v-xv + 1-5, 1-395 icons. Weinheim: J. Cramer.

Wood, R. D., \& Imahori, K. (1965). A revision of the Characeae. I. Monograph of the Characeae, i-xxiv + 1-904. Weinheim: J. Cramer.

Yehuda, G., Barinova, S. S., Krugman, T., Pavlicek, T., Nov, Y., \& Nevo, E. (2013). Microscale adaptive response of charophytes of the Negev Desert, Israel: species divergences by AFLP. Natural Resources and Conservation, 1(3), 55-64. DOI: 10.13189/nrc.2013.010301

\section{Copyright Disclaimer}

Copyright for this article is retained by the author(s), with first publication rights granted to the journal.

This is an open-access article distributed under the terms and conditions of the Creative Commons Attribution license (http://creativecommons.org/licenses/by/3.0/). 